\title{
On the deglaciation chronology of the Palivere ice-marginal zone, northern Estonia
}

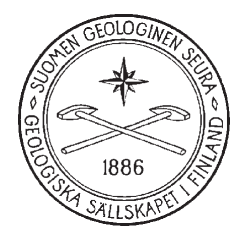

\author{
Leili Saarse ${ }^{1}$, Atko Heinsalu ${ }^{1}$, Simm Veski ${ }^{1}$, \\ LEELI AMON ${ }^{1}$ AND Andrejus GaidaM̌avicius ${ }^{2}$ \\ ${ }^{1}$ Institute of Geology at Tallinn University of Technology, \\ Ehitajate tee 5, 19086 Tallinn, Estonia \\ ${ }^{2}$ Institute of Geology \& Geography, T. Ševčenkos str. 13, \\ LT-03223 Vilnius, Lithuania
}

\begin{abstract}
This paper presents new bio-, litho- and chronostratigraphical evidence from two adjacent sediment sequences of the Tõdva and Saku basins, northern Estonia that refine the age estimate of the Palivere ice-marginal zone and the deglaciation history of Estonia. Previous palynological studies demonstrated the presence of late-glacial sediments in the area; however, those sections were not dated, and their ages were poorly constrained. New accelerator mass spectrometry (AMS) ${ }^{14} \mathrm{C}$ dates show that sedimentation in the Tõdva basin started at approximately $13200 \mathrm{cal}$ yr BP. Therefore, because the studied sites are located at the distal part of this zone, we infer that this age represents the minimum timing of the ice retreat from the Palivere ice-marginal zone.
\end{abstract}

Keywords (GeoRef Thesaurus, AGI): ice-marginal features, deglaciation, chronology, mires, sediments, stratigraphy, microfossils, absolute age, C-14, Quaternary, Palivere, Tõdva, Estonia

Corresponding author email: saarse@gi.ee

Editorial handling: Pertti Sarala

\section{Introduction}

The reconstruction of the deglaciation history of Estonia is based on the recognition of five ice-marginal zones, of which the Palivere ice marginal is the youngest (Raukas, 1986). The so-called Palivere belt in northern and western Estonia is a complex of glacial, glaciofluvial and glaciolacustrine de- posits related to large deltas of ice-dammed lakes (Raukas, 1992; Kalm \& Kadastik, 2001). However, the timing of the formation of the Palivere icemarginal zone remains contentious due to insufficient direct datings and considerable deviations in the available age determinations. Dates of glacio- 
fluvial delta deposits range from $9800 \pm 1300$ to $21000 \pm 2500$ OSL years. Raukas (2009) reported an age of $11300 \pm 1300$ OSL years to be realistic for the formation of the Palivere ice-marginal zone. Surface exposure dating of erratic boulders using the cosmogenic ${ }^{10} \mathrm{Be}$ isotope technique has been applied in studies of the Palivere ice-marginal zone. The ages of 10 erratic boulders ranged from 5200 to $15200{ }^{10}$ Be years with a mean of $13600 \pm 1200$ ${ }^{10}$ Be years (Rinterknecht et al., 2006). Vassiljev et al. (2005) estimated that the Palivere ice-margin readvance commenced at approximately 13 000-13 100 cal yr BP; however, Kalm (2006) reported a younger age of this advance (12700 cal yr BP). Clay varve counts at the Vigala site between the Pandivere and Palivere ice-marginal zones showed an age of 11800 varve years for the Palivere belt (Hang \& Sandgren, 1996).

The objective of this study was to use AMS ${ }^{14} \mathrm{C}$ dating of terrestrial plant macrofossils to track and improve the chronology of the Palivere ice-marginal zone. Radiocarbon dating remains the most prominent method for dating terrestrial macroremains imbedded in late-glacial minerogeneous deposits (Blockley et al., 2007). We selected sediment sections from the Saku and Tôdva mires at the distal region of the Palivere ice-marginal zone, where previous pollen studies confirmed the presence of clayey late-glacial sediments of the Allerød and Younger Dryas age (Veber, 1969).

\section{Setting}

The Saku and Tôdva mires are located $12 \mathrm{~km}$ south of the border of Tallinn at an altitude of 37-37.5 m above sea level (a.s.l.) and encompass a total area of 1130 ha (Fig. 1). These mires form a joint complex, the majority of which is currently drained and used as cultural grassland. The threshold of the mires at ca. $37 \mathrm{~m}$ a.s.l. is covered by alluvial deposits and was possibly eroded to a certain extent during the isolation. The mires are surrounded by tills and glaciofluvial deposits and are underlain by Ordovician limestone (Teedumäe, 1997). Their outline is characterised as winding bottom topography that is uneven with several deeper hollows, where residual lakes persisted and lacustrine lime was deposited during the early Holocene (Veber, 1969). Both basins were flooded by the Baltic Ice Lake (BIL) and were submerged during the Yoldia Sea stage.

Sampling sites in the Saku $\left(59^{\circ} 17^{\prime} 47^{\prime \prime} \mathrm{N}, 24\right.$ $\left.{ }^{\circ} 41^{\prime} 26^{\prime \prime} \mathrm{E}\right)$ and Tôdva mires $\left(59^{\circ} 16^{\prime} 36^{\prime \prime} \mathrm{N}\right.$, $\left.24^{\circ} 43^{\prime} 55^{\prime \prime} \mathrm{E}\right)$ were chosen in locations where pollen analyses were previously conducted and the thickest late-glacial deposits appeared (Veber, 1969). The coring sites were located on the cultivated meadow (Saku) and on the edge of meadow and birch-pine-spruce wood (Tôdva).

\section{Material and methods}

A total of four parallel 280-cm-long sediment cores from the Saku site and four 520-cm-long sediment cores from the Tôdva site were extracted using a 1$\mathrm{m}$-long Russian peat sampler. Overlapping cores were macroscopically described and photographed in the field, wrapped in plastic, transported to the laboratory and stored in a cool room. Sub-samples from clayey deposits (1-cm thickness) were taken continuously for loss-on-ignition (LOI) analyses, whereas $1-\mathrm{cm}$ thickness samples were taken at 5$10 \mathrm{~cm}$ intervals to determine the grain size distribution. Samples for LOI analyses were weighted, dried overnight at $105^{\circ} \mathrm{C}$ and combusted at 525 and $900^{\circ} \mathrm{C}$ to calculate the water content, the abundance of organic matter (OM) and carbonate compounds, respectively. The residue containing the siliciclastic and bioclastic components was described as mineral matter and calculated by subtraction based on the sum of OM and carbonates. The lithic grain size distribution was analysed using a Horiba LA-950V2 laser scattering particle size distribution analyser. The magnetic susceptibility (MS) was measured at a $1-\mathrm{cm}$ resolution using a Bartington Instruments high resolution surface scanning sensor MS2E along carefully cleaned flat surfaces of fresh sediments.

Pollen preparation followed a standard method (Berglund \& Ralska-Jasiewiczowa, 1986; Fægri et al., 1989). A total of 9 samples were analysed. One tablet of Lycopodium spores was added to volumespecific $\left(1 \mathrm{~cm}^{3}\right)$ samples to estimate the pollen con- 


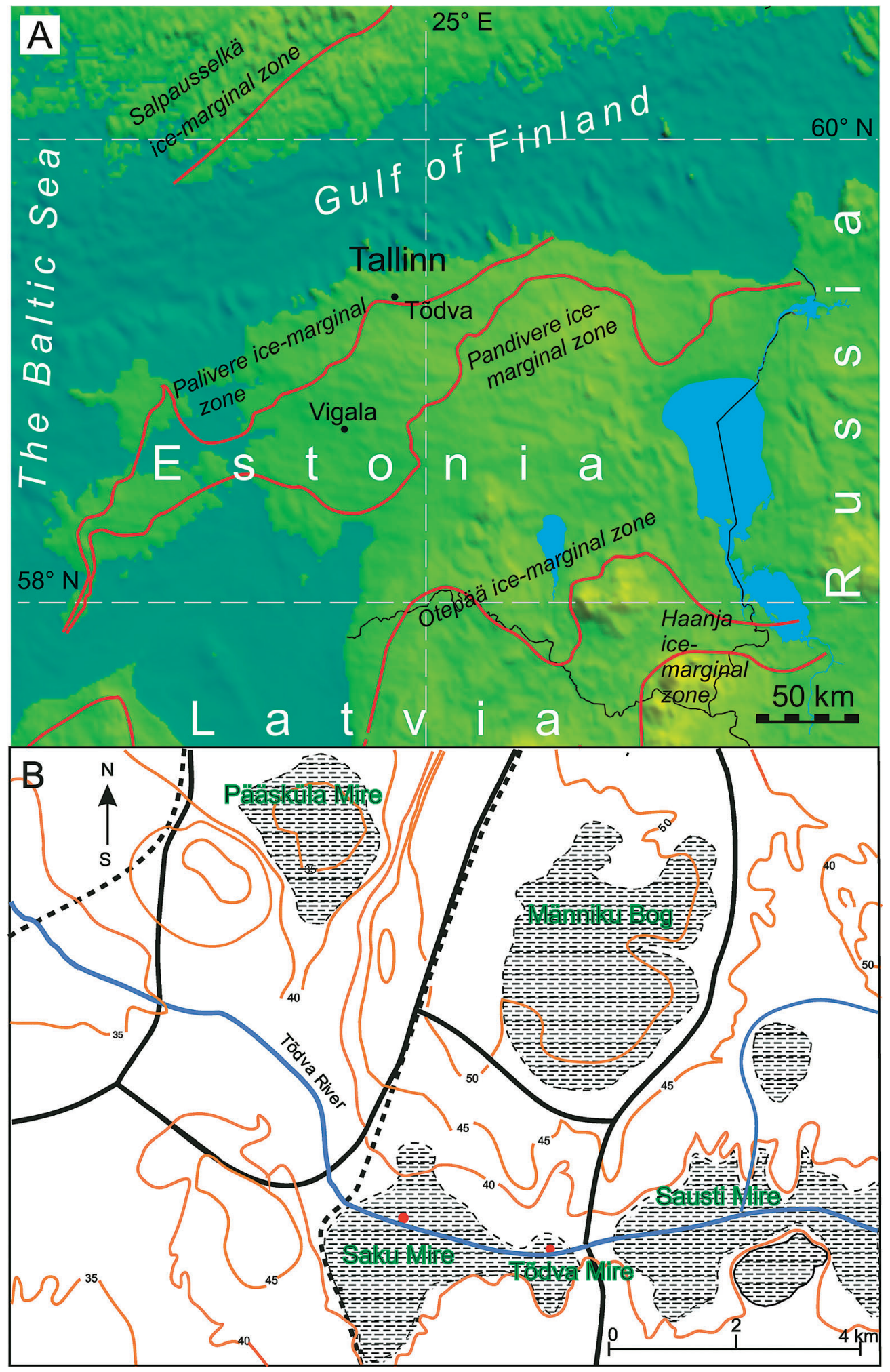

Fig. 1. Location of the study area showing the main ice-marginal zones (A). The Sakala zone is not indicated because it is not clearly defined. Coring sites in the Saku and Tõdva mires indicated by red circles (B). Thick black line marks roads, dotted line - railways, brown colour - isolines. 
centration (Stockmarr, 1971). Only 100-200 pollen grains were counted from each sample due to very low pollen concentration. The percentage calculations were based on the sum of terrestrial pollen, and other identified microfossils were calculated based on the basic pollen sum. The pollen accumulation rate (PAR grains $\mathrm{cm}^{-2} \mathrm{yr}^{-1}$ ) was calculated using the concentration data and a constructed time scale.

For diatom analyses, sediment samples were subjected to sequential treatments with $10 \% \mathrm{HCl}$ and $30 \% \mathrm{H}_{2} \mathrm{O}_{2}$ to remove carbonates and OM. Thereafter, fine and coarse mineral particles were removed by repeated decantation (Battarbee et al., 2001). The cleaned sub-samples were dried onto cover slips and permanently mounted onto microscope slides using a Naphrax medium. The analyses were performed using a Zeiss Axio Imager light microscope at x1000 magnification with oil immersion and interference contrast; diatoms were identified using standard floras. Diatoms were grouped according to their habitat into plankton and periphyton, the latter including benthic, epilithic and epiphytic life forms, and into large-lake and smalllake taxa groups. The LOI, PAR and diatom diagrams were constructed using TILIA and TGView software (Grimm, 2007).

To obtain terrestrial macroremains for AMS dating, sediment cores were cut into 5 - $\mathrm{cm}$-thick sections and washed through $0.25 \mathrm{~mm}$ mesh, and the macroremains were examined under a micros- cope. Late-glacial sediment sub-samples contained very few terrestrial macroremains, and common Phragmites stems and aquatic mosses were present. However, Dryas octopetala leaves were present in the Tôdva sediment core, and woody pieces were observed in the Saku sediment sequence. These and several other macrofossils were dated at the Poznan Radiocarbon Laboratory to obtain a chronology for the studied sediment sequences. In addition, conventional radiocarbon dating of Holocene bulk peat samples was performed at the Institute of Geology at Tallinn University of Technology. The chronology in the text and figures is presented according to calendar years prior to $1950 \mathrm{AD}$ derived by the calibration of radiocarbon ages with IntCal98 calibration curve and CALIB 5.1 software at one sigma range (Stuiver et al., 2005).

\section{Results}

\subsection{Lithostratigraphy}

The Late-glacial and early Holocene sediments of the Tôdva site were divided into four lithostratigraphical units (Table 1). The lowermost beige sandy silt (Tõ-1, 510-520 cm) is overlain by bluishgrey massive clayey silt (Tô-2, 478-510 cm) with low OM and carbonate content (Fig. 2A, Table 1) and showed the highest MS values (Fig. 3). Unit 3 is sandy silt (Tô-3, 447-478 cm) with a rhythmic pattern of dark brown banding (slightly organic)

Table 1. Lithology of the Tõdva core.

\begin{tabular}{|l|l|}
\hline $\begin{array}{l}\text { Depth, cm with } \\
\text { indication unit } \\
\text { name }\end{array}$ & Sediment description \\
\hline $0-220$ & Brownish black Phragmites-Bryales peat, lower portion well decomposed. \\
\hline $220-421$ & Pinkish-beige lacustrine lime distinctly laminated. \\
\hline $421-447 /$ Tõ-4 & Beige lacustrine lime interlayered with bluish silt. \\
\hline $447-478 /$ Tõ-3 & Bluish-grey sandy silt alternation with dark brown layers with scattered mollusc shells. \\
\hline $478-510 /$ Tõ-2 & Bluish-grey clayey silt, massive. \\
\hline $510-520 /$ Tõ-1 & Beige sandy silt. \\
\hline
\end{tabular}


and continuously decreasing MS values (Fig. 3). At $478 \mathrm{~cm}$ upwards, the carbonate content increases slightly, mainly due to the presence of scattered mollusc shells. In the next studied unit (Tõ-4, 421-
$447 \mathrm{~cm}$ ), beige lacustrine lime alternates with bluish silt, which is gradually replaced by lacustrine lime. The OM contents are low throughout the studied sequence, and thus, the mineral matter content is mainly dependent on the amount of carbonate compounds. The sediment grain-size composition is variable and is clayey between 478 and $510 \mathrm{~cm}$ with greater amounts of silty and sandy material in the upper portion (Fig. 4).

The lowest unit of the Saku site (Sa-1, 268-288 cm) consisted of medium sand with low OM and carbonate contents (Fig. 2B). At the upper limit of the unit, the OM content increases due to the occurrence of rootlets that penetrated into the sand. This sand is overlain by clayey silt ( $\mathrm{Sa}$ $2,262-268 \mathrm{~cm}$ ) with a clay fraction of up to $25 \%$ and a OM content of less than $2 \%$. The next unit (Sa-3, 230-262 cm) starts with a thin sand layer $(260-262 \mathrm{~cm})$, followed by sandy silt, where clay fraction decreases. At $245 \mathrm{~cm}$ the carbonate content begins to increase. Sa-4 unit (157-230 $\mathrm{cm})$ is clayey silt consisting of up to $40 \%$ clay; the OM content is constant at approximately $4 \%$, although the carbonate content decreases. In the upper-most silty sand (Sa-5, 147$157 \mathrm{~m}$ ) the sand fraction fluctuates between 50 and $71 \%$, the OM progressively increases in an upward direction and the mineral matter decreases. In the well-decomposed peat (Sa-6), the OM increased from $19 \%$ to $66 \%$ (Fig. 2B).

\subsection{Chronostratigraphy}

The radiocarbon dates presented in Table 2 are variable, and certain values are not consistent with the lithostratigraphical succession. In the
Fig. 2. Distribution of the water content, organic matter, carbonates and mineral matter in the Tõdva (A) and Saku (B) sediment cores. 
Tôdva site, Dryas octopetala leaves at 445-450 cm were dated to $9920 \pm 100(11415 \pm 190 \mathrm{cal} \mathrm{yr} \mathrm{BP}$; Poz-39127). The following AMS date $(9830 \pm 190$; $11250 \pm 425 \mathrm{cal}$ yr BP) at a core depth of 465-475 $\mathrm{cm}$ was not considered in the reconstruction of agedepth model because it was dated using unidenti-

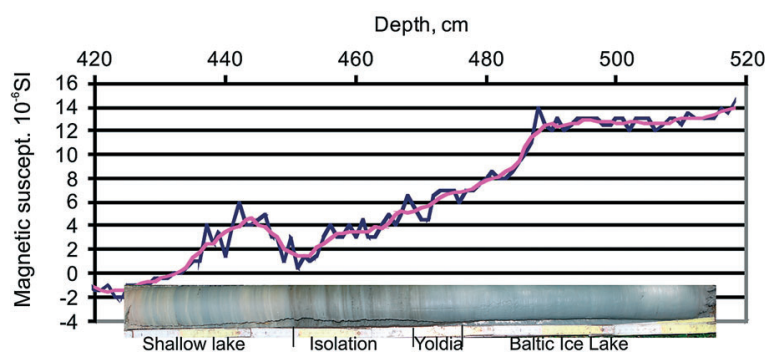

Fig. 3. Photo of the studied sediment core with indication of the magnetic susceptibility (units, $10^{-6} \mathrm{SI}$ ) values and sedimentation environment.

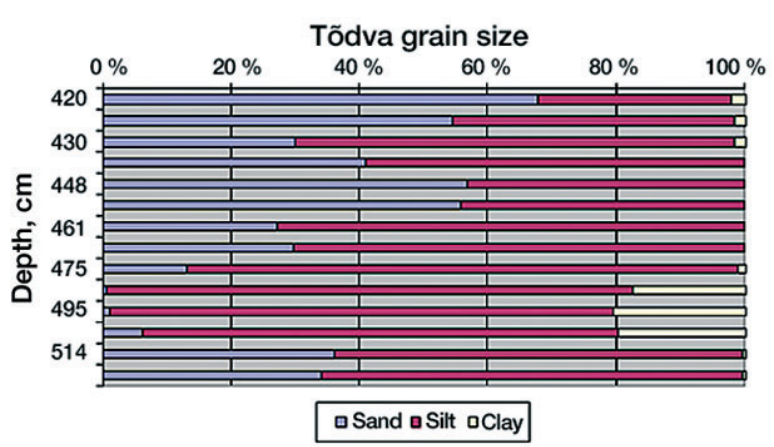

Fig. 4. Summary grain size graph for the Tõdva sediment sequence. fied herb leaves and appears slightly younger that the date presented above. The AMS date of 11310 $\pm 130(13190 \pm 110 \mathrm{cal} \mathrm{yr} \mathrm{BP})$ from the Dryas octopetala leaves at the core depth $515-518 \mathrm{~cm}$ fits well with the pollen stratigraphy and confirms the deposition of the basal sediment at the end of the Allerød period. In the age-depth model, the Younger Dryas/Preboreal boundary of $11650 \mathrm{cal} \mathrm{yr} \mathrm{BP}$ (Lowe et al., 2008) was also considered. All radiocarbon dates for the Saku site demonstrated that the basal clayey deposits, described by Veber (1969) as belonging to the Younger Dryas period, were deposited later in the early Holocene period. Therefore, we presented only the results of the LOI analyses (Fig. 2B) and radiocarbon dates (Table 2).

\subsection{Pollen stratigraphy}

A total of 36 pollen and spore taxa are identified. Pollen concentrations in the Tôdva minerogenic sediments were very low. However, it was possible to differentiate three local pollen assemblage zones; their description is presented in Table 3 and the PAR diagram in Figure 5. According to the pollen analyses and radiocarbon chronology, the sedimentation of silt began at the end of the Allerød and terminated in the Preboreal period.

\subsection{Diatoms}

The massive clayey silts below $478 \mathrm{~cm}$ are devoid of diatoms (Fig. 6). At a core depth from 475 to

Table 2. Radiocarbon dates from the Tõdva and Saku sediments.

\begin{tabular}{|l|l|l|l|l|l|}
\hline $\begin{array}{l}\text { Site } \\
\text { name }\end{array}$ & $\begin{array}{l}\text { Depth, } \\
\text { cm }\end{array}$ & ${ }^{14}$ C date & $\begin{array}{l}\text { Laboratory } \\
\text { number }\end{array}$ & $\begin{array}{l}\text { Calibrated age range BP } \\
\text { (Mean age })\end{array}$ & Dated material \\
\hline Tõdva & $445-450$ & $9920 \pm 100$ & Poz-39127 & $11600-11225(11415 \pm 190)$ & Dryas octopetala leaves \\
\hline Tôdva & $465-475$ & $9830 \pm 190$ & Poz-39129 & $10825-11675(11250+425)$ & Leaves \\
\hline Tôdva & $515-518$ & $11310 \pm 130$ & Poz-39130 & $13080-13300(13190 \pm 110)$ & Dryas octopetala leaves \\
Saku & $137-142$ & $8350 \pm 105$ & Tln-3178 & $9255-9485(9370 \pm 115)$ & Peat \\
Saku & $142-147$ & $8700 \pm 120$ & Tln-3179 & $9545-9825(9685 \pm 140)$ & Peat \\
Saku & $270-275$ & $9070 \pm 70$ & Poz-33494 & $10175-10370(10275 \pm 100)$ & Wood \\
\hline
\end{tabular}




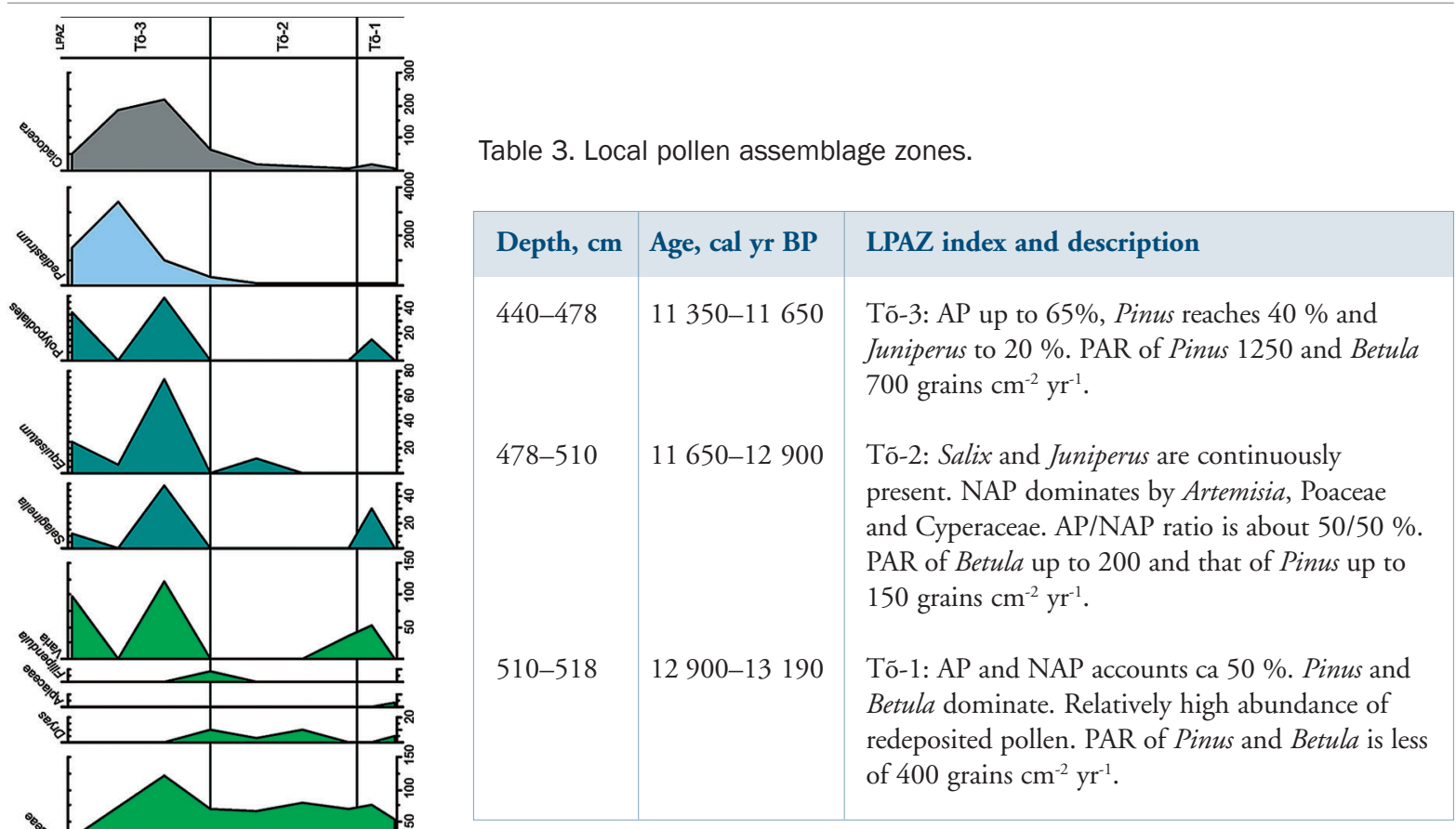

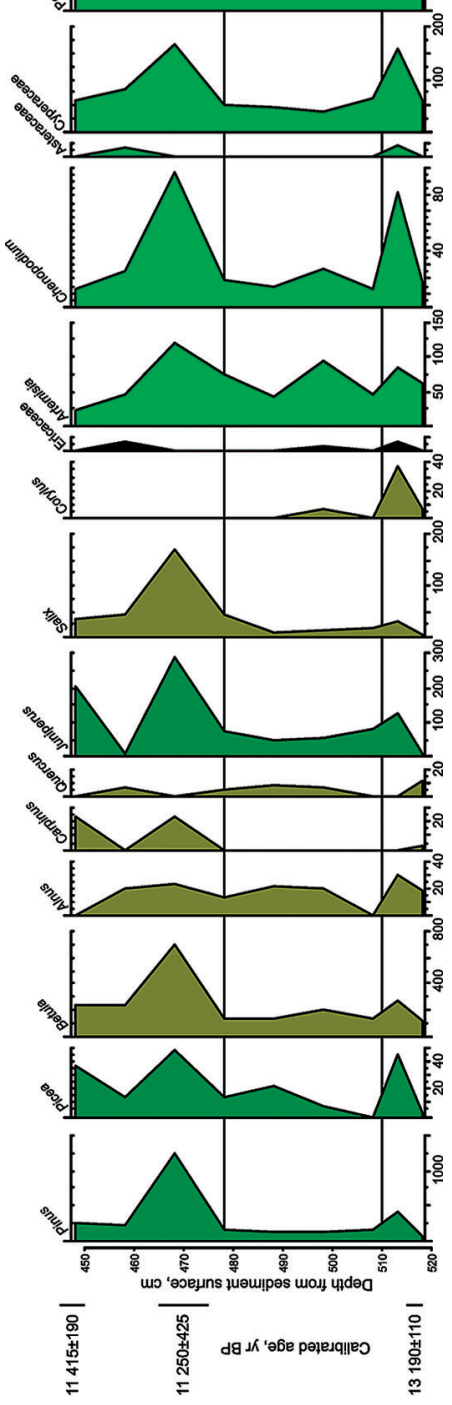

Fig. 5. Pollen accumulation rate (grains $\mathrm{cm}^{-2} \mathrm{yr}^{-1}$ ) of the Tõdva sediment sequence.
$472 \mathrm{~cm}$, the sandy silt contains broken fragments of the benthic diatom Gyrosigma attenuatum, a taxon common in large lakes sediments of Ancylus Lake and the freshwater Yoldia Sea (Heinsalu, 2000, 2001). A common feature of the sediment sequences of small lakes and bogs that were isolated during the freshwater stages of the Baltic Sea is the blooming of Fragilaria species around and after the isolation event. The apparent rise of small-size periphytic fragilarioid diatoms from 468 to $450 \mathrm{~cm}$ may be explained by the basin isolation. From a core depth of $445 \mathrm{~cm}$ Fragilaria spp. decrease and are replaced by diatoms that live in small shallow hard-water lakes, i.e. Mastogloia smithii var. lacustris, Denticula kuetzingii and various Cymbella spp.

\section{Discussion}

The sedimentation model of the Tôdva basin near the Palivere ice-marginal belt provides a basis to suggest that ice retreated from northern Estonia earlier than was previously reported (Vassiljev et al., 2005; Kalm, 2006; Kalm et al., 2011) and the minimum period when the area became free of ice is $13200 \mathrm{cal} \mathrm{yr} \mathrm{BP}$. Such presumption is in good accordance with estimates from Finland, which indicate that the ice margin reached the northern coast of the Gulf of Finland at approximately $13000 \mathrm{cal}$ yr BP (Lunkka et al., 2004) and retreated from the 


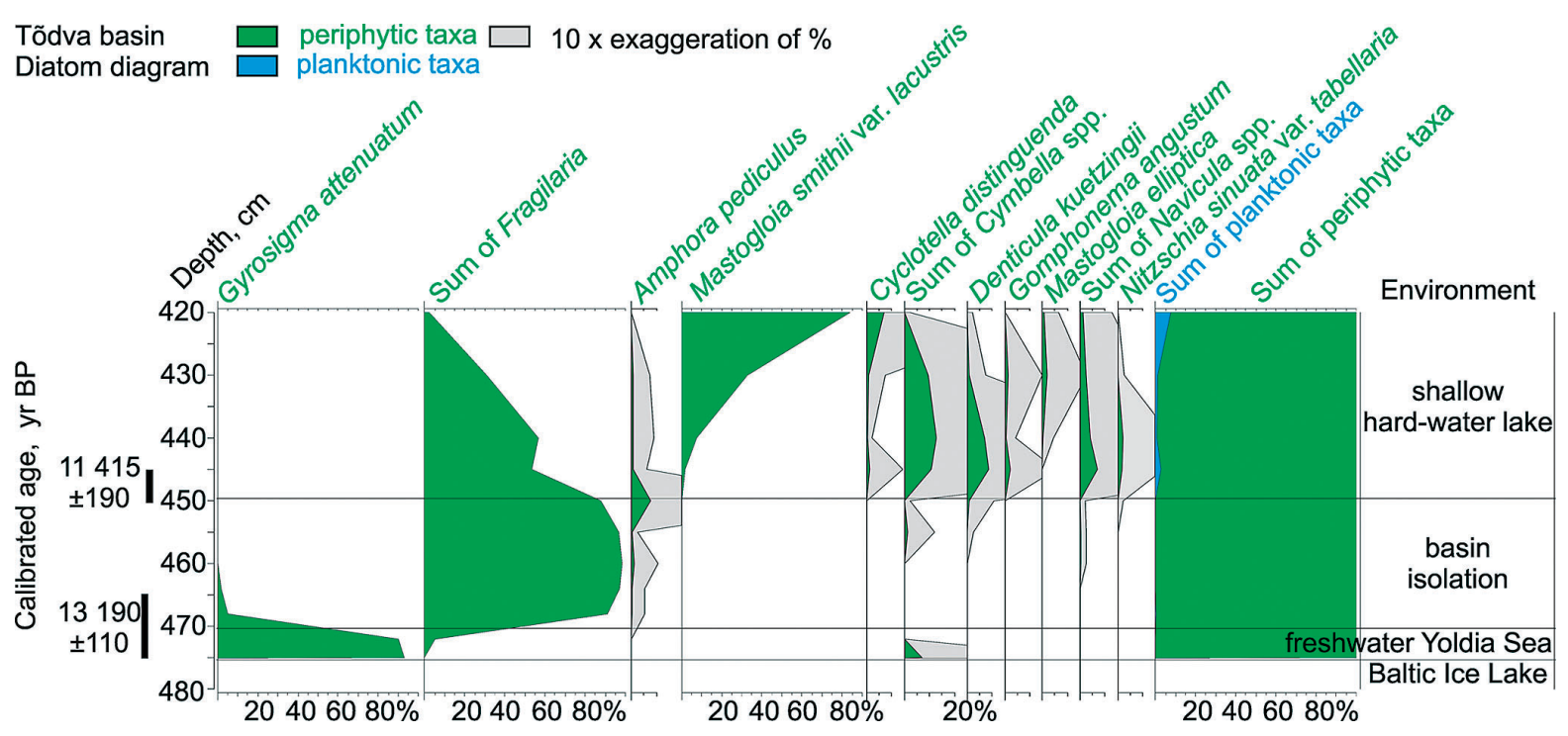

Fig. 6. Diatom stratigraphy of the Tõdva sediment sequence with indications of the sedimentation environments.

Salpausselkä I moraine at $12500 \pm 700{ }^{10} \mathrm{Be}$ yr (Rinterknect et al., 2004) or 12260 cal yr BP (Donner, 2010). Age estimations from the Pandivere ice marginal zone to the south of Palivere show that the ice retreated by at least $13800-13900 \mathrm{cal} \mathrm{yr} \mathrm{BP} \mathrm{(Amon}$ $\&$ Saarse, 2010; Saarse et al., 2009).

During the ice recession, a proglacial lake along the ice margin flooded the study area. Such proglacial lakes have been described and studied in many areas around the world (e.g., Kvasov, 1979; Björck, 1995) and several studies have emphasised their role in the formation of the Younger Dryas climate conditions (Teller et al., 2002; Broecker, 2005). However, the enthusiasm for the flood hypothesis has considerably diminished recently (Broecker et al., 2010; Carlson, 2010).

Recent GIS-based reconstructions have shown that the Palivere ice-marginal zone was linked to the proglacial lake $A_{2}$, a bay of the BIL (Saarse et al., 2007; Rosentau et al., 2007), and the presence of the A phase, as suggested by Pärna (1960), has been questioned. According to water level simulations of the coastline of the BIL located at $71 \mathrm{~m}$ in the study area, the coastlines of the Yoldia Sea and Ancylus Lake were present at $44 \mathrm{~m}$ and $34 \mathrm{~m}$ a.s.l., respectively (Vassiljev, pers. comm.). Rapid drainage of the BIL at $11600 \mathrm{cal} \mathrm{yr} \mathrm{BP}$ caused a remar- kable lowering of water level and left various traces in the sediment sequences that were recorded in several sites with the Baltic region (Haila et al., 1991; Johnson et al., 2010) and in the Gulf of Finland (Hyttinen et al., 2011). In the Tôdva basin, a clear sedimentary limit is present at $478 \mathrm{~cm}$, which is marked by replacement of clayey silt by sandy silt.

The Yoldia Sea stage led to the ingression of sea water that brought brackish water diatom assemblages into the Baltic basin, which is registered in the Gulf of Finland between 11300 and $11200 \mathrm{cal} \mathrm{yr}$ BP (Heinsalu \& Veski, 2007). Diatom evidence indicates that the Tôdva basin was isolated at the beginning of the Yoldia Sea stage prior to the occurrence of the brief brackish water episode. According to the diatom assemblage, the transition from the freshwater Yoldia Sea to the small isolated lake, i.e., basin isolation, occurred between 468 and 450 $\mathrm{cm}$. This interpretation is supported by sediment litho- and biostratigraphy results, e.g., the increased sand content, changes in diatom assemblages and decreased MS values (Figs 3-6).

The analysis of biostratigraphical materials suggests that the study area was free of ice since the end of the Allerød (Fig. 5). Previous pollen stratigraphical studies from several sites within or behind the Palivere ice-marginal belt described pollen assemb- 
lages typical of the Younger Dryas, Allerød and even Older Dryas periods (Pirrus \& Sarv, 1968; Kessel $\&$ Pirrus, 1983). When comparing these pollen diagrams to the radiocarbon-dated Haljala diagram (Saarse et al., 2009), we can see several similarities. Therefore, we conclude that the pollen spectra, which were previously reported as corresponding to the Older Dryas, were clearly formed considerably later during the cooler Allerød period at 13 300-13 100 cal yr BP (Lowe et al., 2008).

In the basal sediment of the Tôdva site, the frequency of Pinus and Betula pollen was between 20 and $30 \%$ (Table 3), which likely reflects a longdistance transport or the redeposition of pollen grains from local overburden (till beds). PAR values of less than 400 grains $\mathrm{cm}^{-2} \mathrm{yr}^{-1}$ suggest treeless tundra-type vegetation at the end of the Allerød and throughout the Younger Dryas period (Fig. 5, Tô$1,2)$. The reason of such an environment is a colder climate, especially during the winter of the Younger Dryas, when the BIL and northern part of the Atlantic Ocean were covered by sea ice (Denton et al., 2005). Such a treeless environment was common to northwestern Estonia (Amon \& Saarse, 2010), which is in contrast to southern Estonia where birch and pine forests were present at the second half of the Allerød (Amon et al., 2012). After the drainage of the BIL near the late-glacial/ Holocene boundary and the formation of the Yoldia Sea, emergent areas were rapidly colonised by vegetation. This colonisation can be determined based on the sharp increase in PAR values (Fig. 5, Tô-3) that confirm the growth of pine and birch trees near the studied site (Hicks, 2001).

\section{Conclusions}

The AMS ${ }^{14} \mathrm{C}$ dating and the pollen records from the Tôdva site confirm that the ice advance from the Palivere ice-marginal zone commenced during the Allerød at approximately $13200 \mathrm{cal} \mathrm{yr} \mathrm{BP.} \mathrm{Ad-}$ ditional AMS dates are needed to resolve the ice recession chronology and address problems associated with the formation of the Palivere ice- marginal belt.

\section{Acknowledgements}

Authors wish to thank Antti E.K. Ojala and anonymous reviewer for valuable comments and suggestions. We are grateful to the Elsevier language editing staff for linguistic help. Funding for this research was provided by the Estonian Ministry of Education and Research (SF0332710s06), the Estonian Research Council (SF140021s12) and ETF Grant 8552.

\section{References}

Amon, L. \& Saarse, L. 2010. Postglacial palaeoenvironmental changes in the surrounding Lake Udriku in North Estonia. Geological Quarterly 54, 85-94.

Amon, L., Veski, S., Heinsalu, A. \& Saarse, L. 2012. Timing of late-glacial vegetation dynamics and respective palaeoenvironmental conditions in southern Estonia: evidence from Lake Nakri sediment record. Journal of Quaternary Science 27, 169-180.

Battarbee, R., Jones, V.J., Flower, R.J., Cameron, N.G., Bennion, H., Carvalho, L. \& Juggins, S. 2001. Diatoms. In: Smol, J.P., Birks, H.J.B. \& Last, W. (eds.) Tracking Environmental Change Using Lake Sediments, Vol. 3: Terrestrial, Algal, and Siliceous Indicators. Kluwer Academic Publishers, Dordrecht, pp. 155-202.

Berglund, B.E. \& Ralska-Jasiewiczowa, M. 1986. Pollen analysis and pollen diagrams. In: Berglund, B.E. (ed.) Handbook of Holocene Palaeoecology and Palaeohydrology. John Wiley and Sons, Chichester, pp. 455-484.

Björck, S. 1995. A review of the history of the Baltic Sea, 13.08.0 ka BP. Quaternary International 27, 19-40.

Blockley, S.P.E., Blaauw, M., Bronk Ramsey, C. \& van der Plicht, J. 2007. Building and testing age models for radiocarbon dates in Lateglacial and Early Holocene sediments. Quaternary Science Reviews 26, 1915-1926.

Broecker, W.S. 2005. The role of the ocean to climate yesterday, today and tomorrow. Columnia University, Eldigio Press, USA. 183 p.

Broecker, W.S., Denton, G.H., Edwards, R.L., Cheng, H., Alley, R.B. \& Putman, A.E. 2010. Putting the Younger Dryas cold event into context. Quaternary Science Reviews 29, 1078-1081.

Carlson, A.E. 2010. What Caused the Younger Dryas Cold Event? Geology 38, 383-384.

Denton, G.H., Alley, R.B.P., Comer, G.C. \& Broecker, W.S. 2005. The role of seasonality in abrupt climate change. Quaternary Science Reviews 24, 1159-1182.

Donner, J. 2010. The Younger Dryas age of the Saplausselkä moraines in Finland. Bulletin of the Geological Society of Finland 82, 69-80.

Fægri, K., Iversen, J., Kaland, P.E. \& Krzywinski, K. 1989. Textbook of pollen analysis, 4th edn. John Wiley and Sons, 
New York. 328 p.

Grimm, E. 2007. Tilia Version 1.0.1. Illinois State Museum. Reserch and Collection Center. Springfield.

Haila, H., Sarmaja-Korjonen, K. \& Uutela, A. 1991. Development of a Litorina Bay at Espoo, near Porvoo, southern Finland. Bulletin of the Geological Society of Finland $63,105-119$.

Hang, T. \& Sandgren, P. 1996. Magnetostratigraphy of varved clays. In: Meidla, T., Puura, I., Nemliher, J., Raukas, A. \& Saarse, L. (eds.) The Third Baltic Stratigraphic Conference. Abstracts. Field Guide. Tartu, pp. 152-154.

Heinsalu, A. 2000. Diatom stratigraphy and palaeoenvironment of the Yoldia Sea in Northern Estonia. Proceedings of the Estonian Academy of Sciences, Geology 49, 218243.

Heinsalu, A. 2001. Diatom stratigraphy and the palaeoenvironment of the Yoldia Sea in the Gulf of Finland, Baltic Sea. Annales Universitatis Turkuensis, ser. A II 144, 141.

Heinsalu, A. \& Veski, S. 2007. The history of the Yoldia Sea in Northern Estonia: palaeoenvironmental conditions and climatic oscillations. Geological Quarterly 51, 295-306.

Hicks, S. 2001. The use of annual arboreal pollen deposition values for delimiting tree-lines in the landscape and exploring models of pollen dispersal. Review of Palaeobotany \& Palynology 117, 1-29.

Hyttinen, O., Kotilainen, A. \& Salonen, V.-P. 2011. Acoustic evidence of a Baltic Ice Lake drainage debrite in the northern Baltic Sea. Marine Geology 284, 139-148.

Johnson, M.D., Stahl, Y., Larsson, O. \& Seger, S. 2010. New exposes of Baltic Ice Lake drainage sediments, Götene, Sweden. GFF 132, 1-12.

Kalm, V. 2006. Pleistocene chronostratigraphy in Estonia, southeastern sector of the Scandinavian glaciation. Quaternary Science Reviews 25, 960-975.

Kalm, V. \& Kadastik, E. 2001. Waterlain glacial diamicton along the Palivere ice-marginal zone on the West Estonian archipelago, eastern Baltic Sea. Proceedings of the Estonian Academy of Sciences, Geology 50, 114-127.

Kalm, V., Raukas, A., Rattas, M. \& Lasberg, K. 2011. Pleistocene Glaciation in Estonia. In: Ehlers, J., Gibbard P.L. \& Huges P.D. (eds.) Quaternary Glaciations - Extent and Chronology. A Closer Look. Elsevier, Amsterdam, pp. 95104.

Kessel, H. \& Pirrus, R. 1983. Some problems concerning stratigraphic subdivision of Estonian late glcial sediments on the basis of palynologic data. In: Bartosh, T. (ed.) Palynologic researches in geologic studies of the Baltic region and the Baltic Sea. Zinatne, Riga, pp. 14-17 (in Russian with an English summary).

Kvasov, D.D. 1979. The Late-Quaternary History of Large Lakes and Inland Seas of Eastern Europe. Annales Academie Scientiarum Fennicae, Ser. A III Geologica-Geographica $127,1-71$.
Lowe, J.J., Rasmussen, S.O., Björck, S., Hoek, W.Z., Steffensen, J.P., Walker, M.J.C., Yu, Z.C. \& the INTIMATE group 2008. Synchronisation of palaeoenvironmental events in the North Atlantic region during the Last Termination: a revised protocol recommended by the INTIMATE group. Quaternary Science Reviews 27, 6-17.

Lunkka, J.P., Johansson. P., Saarnisto, M. \& Sallasmaa, O. 2004. Glaciation of Finland. In: Ehlers, J. \& Gibbard, P.L. (eds.) Quaternary Glaciations - Extent and Chronology. Part I: Europe. Elsevier, Amsterdam, pp. 93-100.

Pirrus, R. \& Sarv, A. 1968. Stratigraphy of Late and Post Glacial deposits in Estonia based on palynological key section. Academy of Sciences Estonian SSR, Institute of Geology. Manuscript in the Institute of Geology at Tallinn University of Technology. Tallinn, 173 p. (in Russian).

Pärna, K. 1960. Zur Geologie des Baltischen Eisstausees Sowie der Lokalen Grossen Eisstauseen auf dem Territorium der Estnischen SSR. Eesti NSV Teaduste Akadeemia Geoloogia Instituudi Uurimused V, 269-278 (in Russian with German summary).

Raukas, A. 1986. Deglaciation of the Gulf of Finland and adjoining areas. Bulletin of the Geological Society of Finland $58,21-33$.

Raukas, A. 1992. Ice marginal formations of the Palivere zone. Sveriges Geologiska Undersökning, ser. Ca 82, 277-284.

Raukas, A. 2009. When and how did the continental ice retreat from Estonia. Quaternary International 207, 50-57.

Rinterknecht, V.R., Clark, P.U., Raisbeck, G.M., Yiou, F., Brook, E.J., Tschudi, S. \& Lunkka, J.P. 2004. Cosmogenic ${ }^{10} \mathrm{Be}$ dating of the Salpausselkä I Moraine in southwestern Finland. Quaternary Science Reviews 23, 22832289.

Rinterknecht, V.R., Clark, P.U., Raisbeck, G.M., Yiou, F., Bitinas, A., Brook, E.J., Marks, L., Zelcs, V., Lunkka, J.P., Pavlovskaya, I.E., Piotrowski, J.A. \&̌ Raukas, A. 2006. The Last Deglaciation of the Southeastern Sector of the Scandinavian Ice Sheet. Science 311, 1449-1452.

Rosentau, A., Vassiljev, J., Saarse, L. \& Miidel, A. 2007. Palaeogeographic reconstruction of proglacial lakes in Estonia. Boreas 36, 211-221.

Saarse, L., Vassiljev, J., Rosentau, A. \& Miidel, A. 2007. Reconstructed late glacial shore displacement in Estonia. Baltica 20, 35-45.

Saarse, L., Niinemets, E., Amon, L., Heinsalu, A., Veski, S. \& Sohar, K. 2009. Development of the late glacial Baltic basin and succession of the vegetation cover as revealed at Palaeolake Haljala, northern Estonia. Estonian Journal of Earth Sciences 58, 317-333.

Stockmarr, J. 1971. Tablets with spores used in absolute pollen analysis. Pollen et Spores 13, 615-621.

Stuiver, M., Reimer, P.J. \& Reimer, R. 2005. CALIB Radiocarbon Calibration (HTML Version 5.0). http:// radiocarbon.pa.qub.ac.uk/calib/

Teedumäe, A. 1997. Carbonate rocks. In: Raukas, A. \& Teedu- 
mäe, A. (eds.) Geology and mineral resources of Estonia. Estonian Academy Publishers, Tallinn, pp. 348-356.

Teller, J.T., Leverington, D.W. \& Mann, J.D. 2002. Freshwater outburst to the oceans from glacial Lake Agassiz and their role in climate change during the last glaciation. Quaternary Science Reviews 21, 879-887.
Vassiljev, J., Saarse, L. \& Miidel, A. 2005. Simulation of proglacial lake shore displacement in Estonia. Geological Quarterly 49, 251-263.

Veber, K. 1969. Das Moor Saku. Eesti Maaviljeluse ja Maaparanduse Teadusliku Uurimise Instituudi Teaduslike tööde kogumik XVI, 248-274 (in Estonian with German summary). 